\title{
Phytohemagglutinin Skin Test
}

National Cancer Institute

\section{Source}

National Cancer Institute. Phytohemagglutinin Skin Test. NCI Thesaurus. Code C129757.

A test used to evaluate patient cell-mediated immune responsiveness. A small amount of the purified plant lectin phytohemagg lutinin protein is placed under the skin. For subjects with normal immunity, non-specific lymphocyte proliferation and infiltration is induced at the injection site. 